\title{
Characterization of Botrytis cinerea causing grape bunch rot in Chinese vineyards
}

\author{
Jayawardena RS ${ }^{1,2}$, Zhang $\mathrm{W}^{1}$, Li XH' ${ }^{1}$, Liu M${ }^{1}$, Hao YY ${ }^{3}$, Zhao $\mathrm{WS}^{4}$, Hyde KD ${ }^{2}$, \\ Liu JH' ${ }^{1}$, Yan JY ${ }^{1}$ \\ ${ }^{1}$ Institute of Plant and Environment Protection, Beijing Academy of Agriculture and Forestry Sciences, Beijing 100097, \\ People's Republic of China \\ 2 Center of Excellence in Fungal Research, Mae Fah Luang University, Chiang Rai. 57100, Thailand \\ 3 The Yellow River Delta Sustainable Development Institute of Shandong Province, Dongying 257091, People's \\ Republic of China \\ 4 Department of Plant Pathology, China Agricultural University, Beijing 100193, People's Republic of China
}

Jayawardena RS, Zhang W, Li XH, Liu M, Hao YY, Zhao WS, Hyde KD, Liu JH, Yan JY 2018 Characterization of Botrytis cinerea causing grape bunch rot in Chinese Vineyards. Asian Journal of Mycology 1(1), 74-87, Doi 10.5943/ajom/1/1/6

\begin{abstract}
Botrytis is an important plant pathogenic genus causing bunch rot of grape berries and other hosts worldwide. A survey of vineyards in 14 provinces of China was carried out to identify the causal agent of Botrytis bunch rot. A phylogenetic analysis based on a combination of RPB2, HSP60, G3PDH and Nep1, Nep2 loci, coupled with morphology, showed that Botrytis cinerea is the main causal agent of grape bunch rot disease in China. Pathogenicity tests showed that wounded grape berries are more susceptible to Botrytis cinerea infection than non-wounded berries. This paper contributes to the fact that Nep1 and Nep2 gene regions provide a higher resolution in distinguishing species of Botrytis.
\end{abstract}

Key words - Gray mold - Grapevine - Nep1 - Nep2 - Pathogen

\section{Introduction}

Grapevine (Vitis vinifera L., family Vitaceae) is one of the most widely cultivated crops worldwide. China holds the first position among Asian countries in cultivating wine grapes with 580,000 hectares (IOV 2013). As this crop has become more widely grown in China, many fungal, bacterial, and viral diseases have become major problems for grapevine cultivation, especially fungal diseases (Jayawardena et al. 2014).

Botrytis Pers. (Sclerotiniaceae, Ascomycota) was introduced by Micheli (1729) and later validated by Persoon (Jarvis 1980). It was one of the first described genera of fungi (Hyde et al. 2014). It is recommended to use the name Botrytis over its sexual morph Botryotinia, since Botrytis is the oldest and the most commonly used name (Kirk et al. 2013, Hyde et al. 2014). Botrytis species are important pathogens of many agro-economic crops such as grapes, kiwifruit, lettuces, tomato, strawberry and ornamental crops (Giraud et al. 1999, Fournier et al. 2005, Staat et al. 2005). Species of Botrytis cause gray mold disease on more than 200 mostly dicotyledonous plant species (Williamson et al. 2007). Gray mold infection leads to serious losses in yield and quality under humid conditions on numerous crops, particularly fruits, vegetables and ornamental flowers (Leroch et al. 2012). Gray mold caused by Botrytis species is probably the most important pre- and 
postharvest disease of grapevine. Northern Chinese vineyards are frequently affected by gray mold (Chen et al. 2006) (Fig 1).

In China, the causal agent of gray mold has long been identified as B. cinerea (Du et al. 1992, Lei et al. 2005, Chen et al. 2006, Zhou et al. 2014), which is considered to be a typical heterothallic fungus. Botrytis pseudocinerea A.S. Walker et al. and B. sinoviticola J. Zhang et al. are also recognized to cause bunch rot of grapevine in China (Zhou et al. 2014). The aim of the current paper is to identify and characterize the Botrytis species occurring on grapevine in China using both morphological and molecular data. This is the eleventh contribution in a series of papers reassessing the genera and species of fungi causing grapevine diseases in China (Yan et al. 2013, 2014, Dissanayake et al. 2014, Jayawardena et al. 2014, Liang et al. 2015).
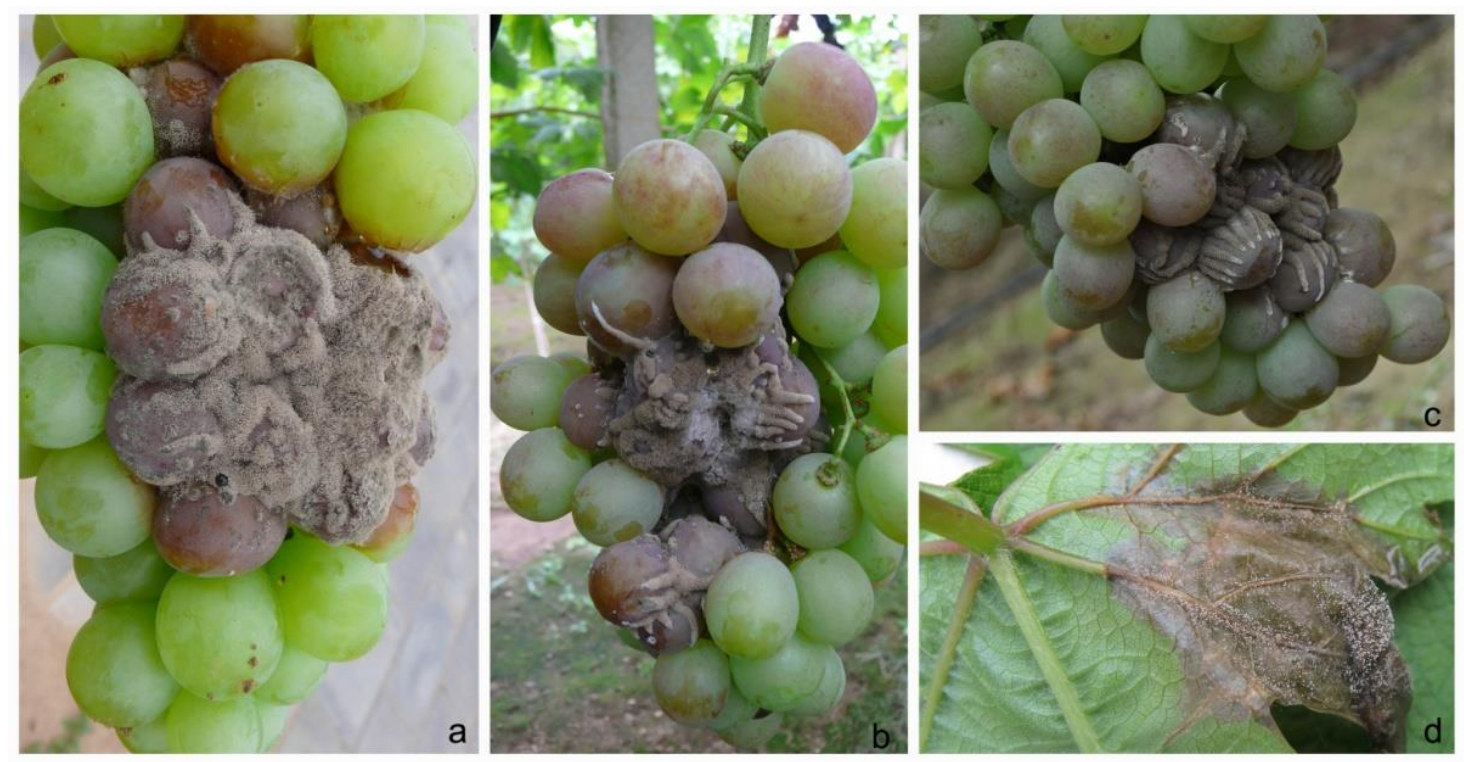

Fig. 1 - Disease symptoms of Botrytis on grapes in a vineyard. a-c Botrytis on grape bunch. d Botrytis on a leaf

\section{Materials \& Methods}

\section{Isolation and Identification}

Isolates were collected from Beijing, Gansu, Guangxi, Hebei, Henan, Hubei, Hunan, Jiangsu, Liaoning, Ninxia, Shandong, Shanghai, Shanxi, Tianjin and Zhejiang provinces of China. Diseased grapevine samples were collected and placed in separate plastic bags with sterilized tissues dipped in distilled water to maintain humidity. Samples were surface sterilized with $75 \%$ ethanol for 1 minute and then rinsed three times with water. The fungi, present on samples were isolated by single spore culture technique (Chomnunti et al. 2014). The pure isolates obtained were cultured on potato dextrose agar (PDA) plates with sterilized filter paper pieces and incubated for 7-10 days at $25{ }^{\circ} \mathrm{C}$. Cultures on the filter paper pieces were dried on sterilized filter paper and stored at $-20{ }^{\circ} \mathrm{C}$. The morphology of fungal colonies was recorded following the method of Hennebert (1963), Zhang et al. (2010 a, b) and Zhou et al. (2014). Fungal mycelia and spores were observed and photographed using a Leica DM5500B microscope.

\section{Molecular Phylogeny}

\section{DNA extraction, PCR amplification, and DNA sequencing}

Isolates were transferred to $90 \mathrm{~mm}$ diameter Petri dishes containing PDA. Total genomic DNA was extracted from fresh cultures $(500 \mathrm{mg})$, scraped from the margin of a colony on a PDA plate incubated at $25{ }^{\circ} \mathrm{C}$ for 7-10 days. The method of Zhang et al. (2010 a, b) was used for DNA 
extraction with minor modifications. The RPB2, HSP60, GPDH, Nep1, Nep2 genes were amplified using primer pairs RPB2for+/RPB2rev+ (Staats et al. 2005), HSP60for+/HSP60rev+ (Staats et al. 2005), G3PDHfor+/ G3PDHrev+ (Staats et al. 2005), Nep1(-207)for/Nep1(+1124)rev (Staats et al. 2007 a, b), Nep2(-200)for/Nep2(+1147) rev (Staats et al. 2007 a, b), respectively. The PCR was performed in a BIORAD $1000^{\mathrm{TM}}$ Thermal Cycler in a total volume of $25 \mu$. The PCR mixtures contained TaKaRa Ex-Taq DNA polymerase $0.3 \mu 1,12.5 \mu \mathrm{l}$ of $2 \times$ PCR buffer with $2.5 \mu 1$ of dNTPs, $1 \mu 1$ of each primer, $9.2 \mu 1$ of double-distilled water and 100-500 ng of DNA template. The thermal cycling program followed Li et al. (2012). The PCR products were verified by staining with ethidium bromide on $1.2 \%$ agarose electrophoresis gels and purified according to the manufacturer's instructions of a Qiangen purification kit (Qiagen, USA) and for ligation PMD $18 \mathrm{~T}$ vector (Takara Company, Dalian, China) was used. The DNA sequences of RPB2, HSP60, G3PDH, Nep1 and Nep2 regions generated in this study were submitted to GenBank.

\section{Phylogenetics analysis}

DNAStar and SeqMan were used to obtain consensus sequences from data generated from forward and reverse primers. Single and combination of multi-locus datasets of the gene regions were aligned using Clustal X1.81 (Thompson et al. 1997). The sequences were further aligned using default settings of MAFFT v.7 (Katoh \& Toh 2008; http://mafft.cbrc.jp/alignment/server/) and manually adjusted using BioEdit (Hall 1999) where necessary. A maximum parsimony analysis (MP) was performed using PAUP (phylogenetic analysis using parsimony) v. 4.0b10 (Swofford 2002). Ambiguously aligned regions were excluded and gaps were treated as missing data. Trees were inferred using the heuristic search option with tree bisection reconnection (TBR) branch swapping and 1,000 random sequence additions. Maxtrees were set to 5,000 branches of zero length were collapsed, and all multiple parsimonious trees were saved. Tree length (TL), consistency index (CI), retention index (RI), rescaled consistency index (RC), and homoplasy index (HI) were calculated for trees generated under different optimality criteria. The robustness of the most parsimonious trees was evaluated by 1000 bootstrap replications resulting from maximum parsimony analysis (Hillis \& Bull 1993). The Kishino-Hasegawa tests (Kishino \& Hasegawa 1989) were performed in order to determine whether the trees inferred under different optimality criteria were significantly different.

In addition, Bayesian inference (BI) was used to construct the phylogenies using Mr. Bayers v. 3.1.2 (Ronquist et al. 2012). MrModeltest v. 2.3 (Nylander 2004) was used to carry out statistical selection of best-fit models of nucleotide substitution. Six simultaneous Markov chains were run for 1,000,000 generations and trees were sampled every 100th generation. The first 2,000 trees, representing the burn-in phase of the analyses, were discarded and the remaining 8,000 trees used for calculating posterior probabilities (PP) in the majority rule consensus tree. Phylogenetic trees were drawn using Treeview (Page 1996). The alignments and trees are deposited in TreeBASE (www.treebase.org/treebase/index.html). The fungal strains that were used for this study are listed in Table 1.

\section{Pathogenicity test}

Pathogenicity tests were conducted on healthy fruit of Vitis vinifera cv. Red Globe that were uniform in size and lacking visible disease symptoms. The experiment comprised 40 fruits (including 10 controls). The fruits were washed with tap water and then disinfected in 1\% sodium hypochlorite for 1-3 minutes. Disinfected fruits were washed three times with distilled, sterilized water and then dried with sterilized filter paper, before inoculation. Inoculations used wound and non-wound inoculation methods. A sterile needle was used to prick the fruit wall, and a $5 \mathrm{~mm}$ diam. PDA agar disk was placed on the wound. The non-wound inoculation method involved placing PDA agar disks ( $5 \mathrm{~mm}$ diam.) on the fruit without pricking the fruit wall. Controls were inoculated with a sterile agar plug. All the fruit were incubated in a moist chamber at $\pm 95 \%$ relative humidity and at $28{ }^{\circ} \mathrm{C}$ until symptoms appeared. Re-isolations were made to confirm Koch's postulates. 


\section{Data analysis}

Data from the pathogenicity tests were analyzed using Minitab, V.15.1.1.0 (Minitab release 15.1.1.0, Minitab, Boston, MA, USA). Treatment means were compared using Turkeys' test at the $5 \%$ significance level.

\section{Results}

\section{Isolation of fungi}

Botrytis species were isolated from berries with grey-brown mycelium and from reddish brown necrotic lesions (Fig. 1). Twenty-seven isolates were obtained from disease samples and deposited in Beijing Academy of Agriculture and Forestry Sciences culture collection. Isolates were obtained from 16 grape varieties including three traditional varieties (cv. brier grape, cv. JinXiangyu, cv. Shanghai pei one).

\section{Phylogenetic analysis}

Phylogenetic trees were constructed using combined sequence data from RPB2, HSP60 and GPDH for our isolates of Botrytis and with those that originated from Hyde et al. (2014), Zhou et al. (2014) (Table 1). A separate phylogenetic tree was constructed using combined sequences of Nep1 and Nep2 for our isolates and with those that originated from Hyde et al. (2014). Maximumparsimony and Bayesian inference analyses produced nearly identical topologies (Bayesian trees are not shown).

The combined gene alignment comprised 63 taxa and 2939 characters including gaps (GADPH: 1-893, HSP60: 894-1854, RPB2: 1855-2939), with Sclerotinia sclerotiorum (strain 484 ) as the out group taxon. Parsimony analysis indicated that 2261 characters were constant, 321 variable characters uninformative and 357 characters parsimony-informative. Parsimony analysis resulted in ten most parsimonious trees, one of them is shown (Fig. 2$)(\mathrm{TL}=1109, \mathrm{CI}=0.710, \mathrm{RI}=$ $0.908, \mathrm{RC}=0.644, \mathrm{HI}=0.290$ ).

Combined gene analysis of Nep1 and Nep2 comprised 57 taxa and 1581 characters including gaps. Parsimony analysis indicated that 999 characters were constant, 190 variable characters uninformative and 392 characters parsimony-informative. Parsimony analysis resulted in ten most parsimonious trees, one of them is shown (Fig. 3) $(\mathrm{TL}=1071, \mathrm{CI}=0.657, \mathrm{RI}=0.882, \mathrm{RC}=0.580$, $\mathrm{HI}=0.343$ ).

Bootstrap support (BS) values and Bayesian posterior probabilities (PP) (equal to or above $50 \%$ based on 1,000 replicates) are shown near the nodes. Combined gene analysis resulted in clustering of our isolates with $B$. cinerea with strong support.

\section{Botrytis cinerea Pers., Ann. Bot. (Usteri) 1: 32 (1794)}

Index Fungorum number: IF217312; Faces of fungi number: FoF03822

Synonyms in Index Fungorum (2018)

At the onset of ripening (verasion), grapes are infected either directly through the epidermis or through wounds. The fungus then progressively invades the entire cluster. Infected berries first appear soft around the lesion, with ruptured skin that is covered with grey mycelium. Later, the skin appears to be sunken and watery around the lesion, and covered with grey mycelium and conidial mass (Fig. 1). Twenty-seven isolates obtained from the diseased samples in this study were identified as B. cinerea. For morphology (Fig. 4) refer to Aktaruzzaman et al. (2017).

\section{Pathogenicity test}

Lesions resembling initial symptoms were observed after 6 days on leaves. The lesion obtained by wound inoculation method were longer $(\bar{x}=2.07 \mathrm{~cm})$ than the lesions obtained by nonwound inoculation method $(\bar{x}=0.52 \mathrm{~cm})$. Botrytis cinerea was successfully re-isolated from the wounded and unwounded grapevine fruit. Control fruit remained healthy (Fig. 5). 


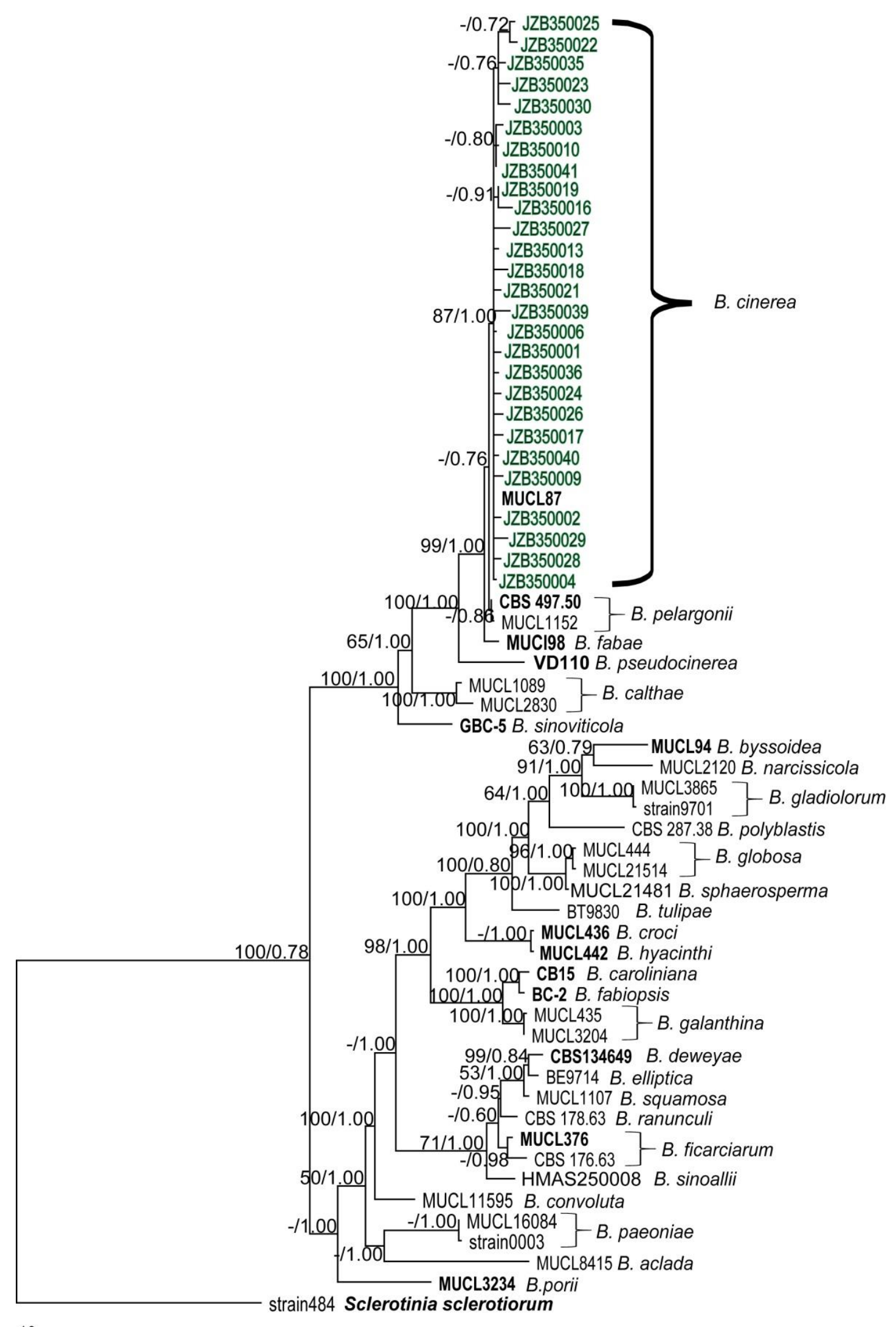

$\underline{10}$

Fig. 2 - Maximum parsimonious tree obtained from a heuristic search of the combined RBP2, GAPH and HSP60 sequence alignment. Bootstrap support values above $50 \%$ and Bayesian posterior probability values above 0.5 are shown near the nodes. Sclerotinia sclerotiorum (strain 484) is used as outgroup. Isolates obtained in this study are shown in green. Ex-type and exepitype strains are in bold. 


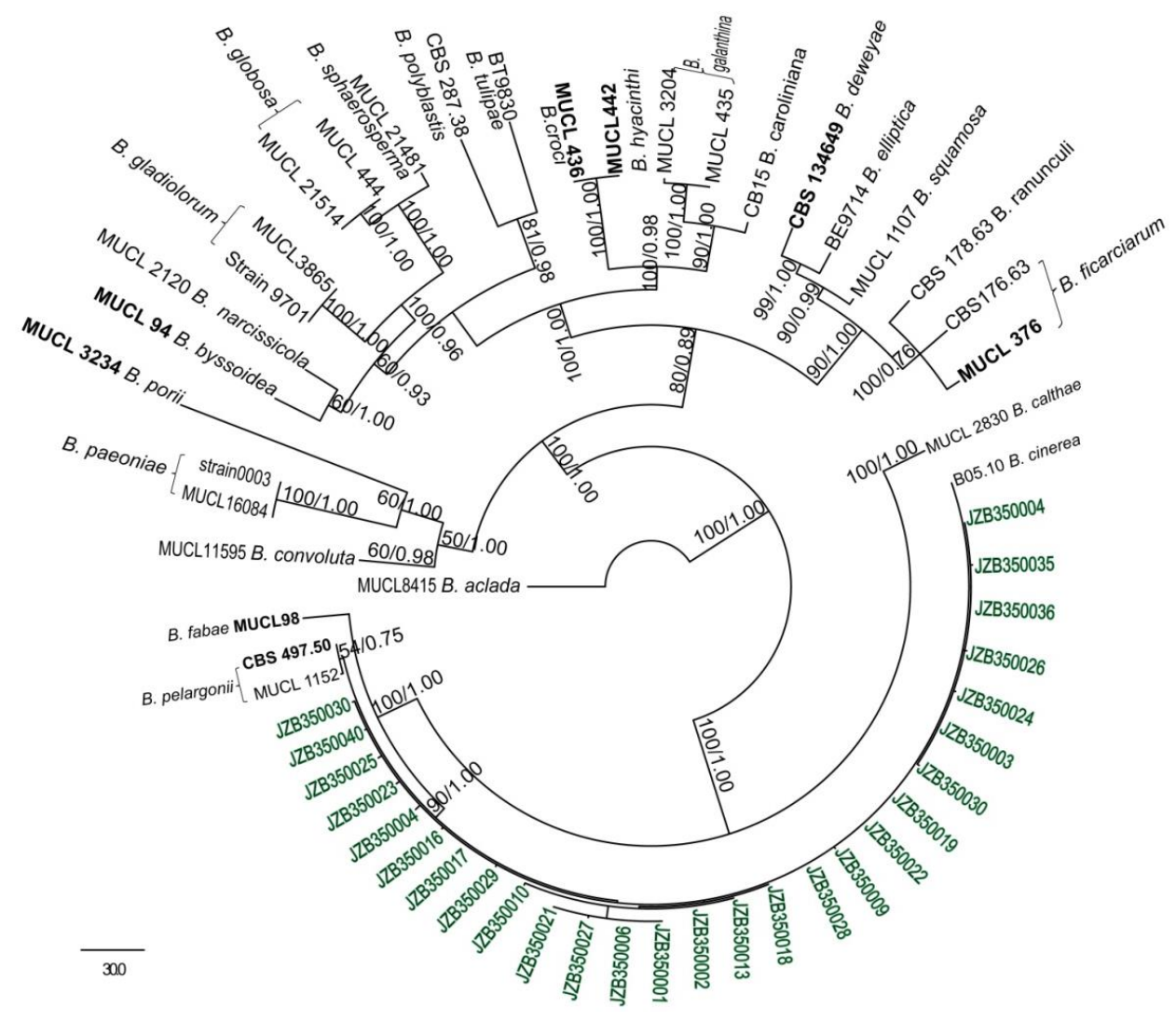

Fig. 3 - Maximum parsimonious tree obtained from a heuristic search of the combined Nep1 and Nep2 sequence alignment. Bootstrap support values above $50 \%$ and Bayesian posterior probability values above 0.5 are shown near the nodes. Isolates obtained in this study are shown in green. Extype and ex-epitype strains are in bold.

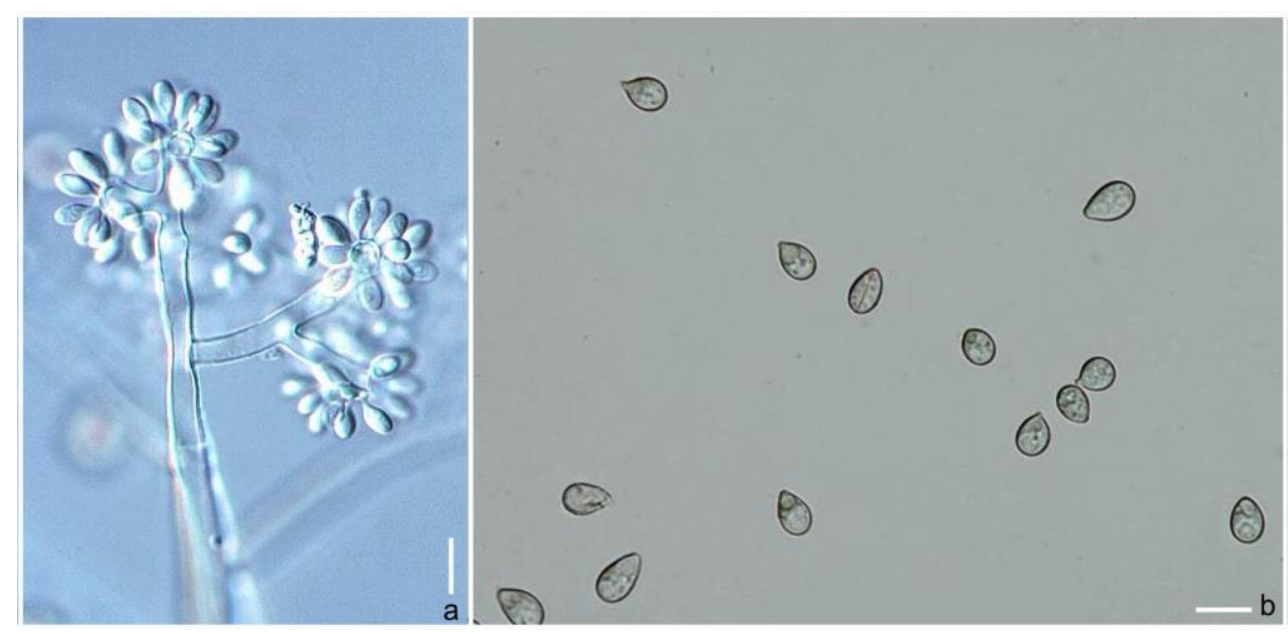

Fig. 4 - Botrytis cinerea. a Many rounded conidia are budded off at the branched ends of the long upright conidiophores. $\mathrm{b}$ Multinucleate, ellipsoid to obovoid conidia. Scale bars: $=20 \mu \mathrm{m}$.

\section{Discussion}

Botrytis cinerea causes leaf blight, shoot blight, inflorescence blight and bunch rot of grapevines and is also the agent of noble rot on grapevine, which is used for the production of sweet wine (Fournier et al. 2005, Wang et al. 2010, Zhou et al. 2014). Among these diseases, Botrytis bunch rot is one of the major fruit rot diseases of grapevines (Cappellini et al. 1986, Chen et al. 2006, Zhou et al. 2014). Botrytis species are responsible for reducing the quality and quantity of grapes by premature cluster drop and postharvest bunch rot (Morris 1985). The fungus infects 
the grapes directly through the epidermis or through old wounds and progressively invades the clusters (Zhou et al. 2014). Compact clusters are the most susceptible for Botrytis bunch rot. During dry weather, infected berries tend to dry out, but in wet weather, brownish or grey mold forms on the surface of the infected berries (Nelson 1951a,b, Vail \& Marios 1991, Vail et al. 1998). In wine production, Botrytis bunch rot will result in off-flavored wines due to the modified chemical composition of diseased berries (Gadoury et al. 2007).

Botrytis cinerea is the best-studied species in the genus (Williamson et al. 2007, Staats et al. $2007 \mathrm{a}, \mathrm{b}$ ) and was recently selected as the second most important plant pathogenic fungal species in the world (Dean et al. 2012). It is the most common pathogen causing Botrytis bunch rot, although population genetic studies have demonstrated that it is a species complex (Giraud et al. 1997, 1999, Albertini et al. 2002, Fournier et al. 2003, 2005, Walker et al. 2011, Hyde et al. 2014). Giraud et al. (1997) proposed two varieties in the $B$. cinerea complex based on the presence or absence of the transposable elements Boty and Flipper; B. cinerea var. transposa and B. cinerea var. vaccuma. In vineyards, particularly at harvest, transposa strains are predominant (Esterio et al. 2011, Giraud et al. 1997, Muñoz et al. 2002, Samuel et al. 2012), while vacuma strains are detected mainly on floral residues and strongly decrease during summer (Vercesi et al. 2014). The use of a Bc-hch population marker also suggested the existence of two groups (I and II) in B. cinerea populations (Fournier et al. 2003). Multi-gene phylogenetic analysis (Staats et al. 2005, Walker et al. 2011, Hyde et al. 2014) also support the two-group classification proposed by Fournier et al. (2003). Walker et al. (2011) defined the Group I isolates of B. cinerea as B. pseudocinerea.
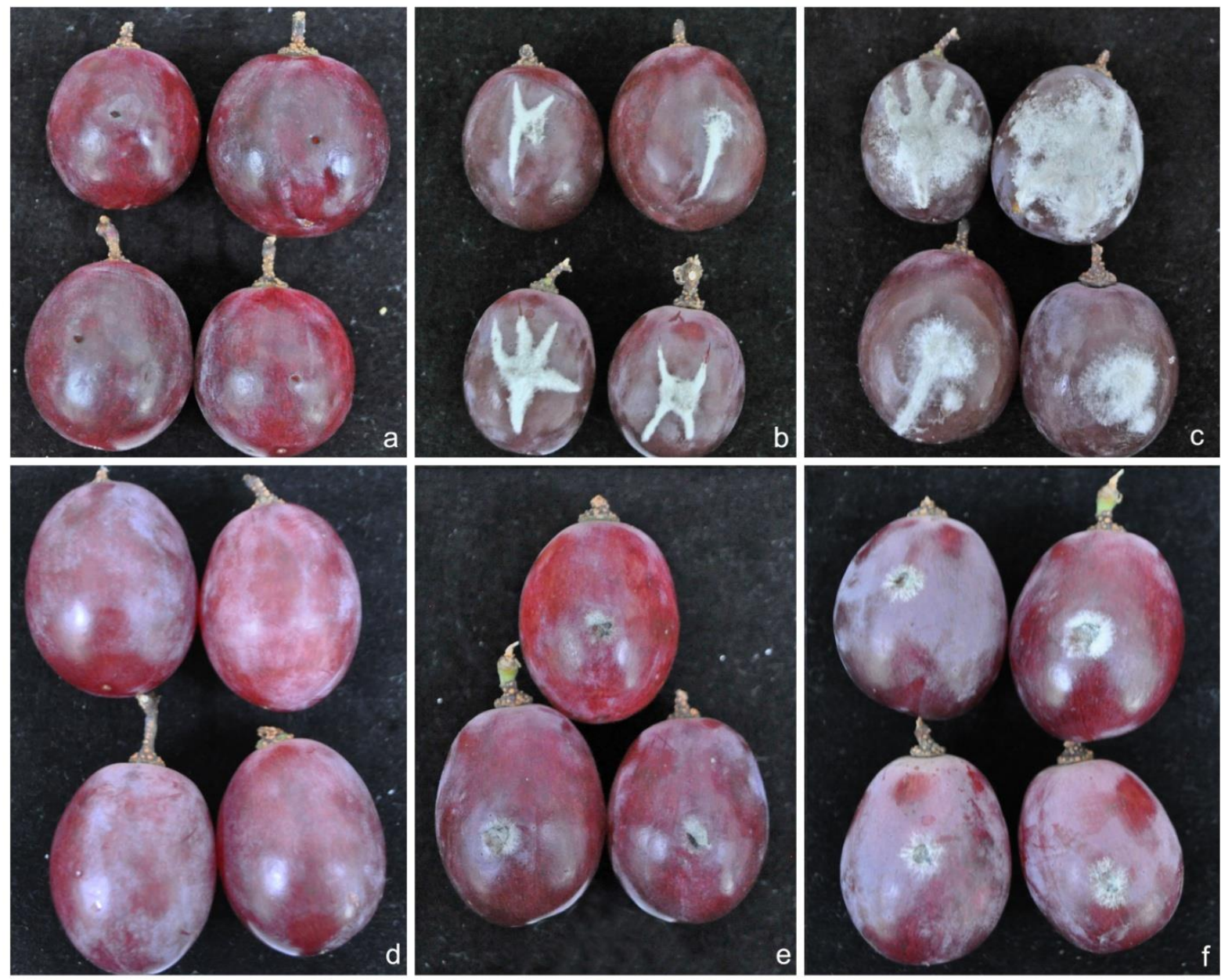

Fig. 5 - Symptoms on fruits of $V$. vinifera inoculated with $B$. cinerea. a, b, c Fruit inoculated with wounding. d, e, f Fruit inoculated without wounding. a, d Control. b, e Lesions with soft tissue and covered with ash coloured mycelium 7 days after inoculation. c, f Lesions with sunken and watery appearance 10 days after inoculation. 
Table 1 Strains included in this study and their corresponding GenBank accession numbers. Ex-type strains are in bold and marked with an *, reference strains are also in bold.

\begin{tabular}{|c|c|c|c|c|c|c|c|}
\hline \multirow[t]{2}{*}{ Species } & \multirow{2}{*}{$\begin{array}{l}\text { Culture } \\
\text { accession } \\
\text { numbers }{ }^{1}\end{array}$} & \multirow[t]{2}{*}{ Hosts } & \multicolumn{5}{|c|}{ GenBank accession numbers ${ }^{2}$} \\
\hline & & & RPB2 & HSP60 & G3DPDH & Nep1 & Nep2 \\
\hline Botrytis aclada & MUCL8415 & Allium spp. & AJ745664 & AJ716050 & AJ704992 & AM087059 & AM087087 \\
\hline $\begin{array}{l}\text { Botrytis } \\
\text { byssoidea }\end{array}$ & MUCL94 & Allium spp. & AJ745670 & AJ716059 & AJ704998 & AM087045 & AM087079 \\
\hline Botrytis calthae & MUCL1089 & Caltha palustris & AJ745672 & AJ716061 & AJ705000 & AM087031 a & AM087088a \\
\hline \multirow[t]{26}{*}{ Botrytis cinerea } & MUCL87 & $>200$ species & AJ745676 & AJ716065 & AJ705004 & DQ211824a & DQ211825a \\
\hline & JZB350001 & Vitis vinifera & KT124647 & КT021839 & NA & NA & КT070547 \\
\hline & JZB350002 & Vitis vinifera & NA & KT021832 & КТ003224 & КT070527 & КT070544 \\
\hline & JZB350003 & Vitis vinifera & NA & KT021833 & KT003226 & NA & KT070552 \\
\hline & JZB350004 & Vitis vinifera & КT021849 & KT021828 & NA & КT070517 & КT070534 \\
\hline & JZB350006 & Vitis vinifera & КT021860 & NA & КТ003232 & NA & KT070548 \\
\hline & JZB350009 & Vitis vinifera & KT021853 & NA & KT003225 & KT070521 & KT070538 \\
\hline & JZB350010 & Vitis vinifera & NA & KT021842 & KT003238 & KT070529 & \\
\hline & JZB350013 & Vitis vinifera & KT021867 & KT021845 & KT003241 & KT070526 & KT070543 \\
\hline & JZB350016 & Vitis vinifera & NA & KT021847 & KT003243 & NA & KT070549 \\
\hline & JZB350017 & Vitis vinifera & KT021855 & KT021834 & КT003228 & NA & КT070546 \\
\hline & JZB350018 & Vitis vinifera & КT021865 & КT021843 & КТ003239 & КT070524 & КT070541 \\
\hline & JZB350019 & Vitis vinifera & KT021868 & KT021846 & KT003242 & KT070518 & КT070535 \\
\hline & JZB350021 & Vitis vinifera & KT021862 & NA & KT003235 & KT070530 & KT070556 \\
\hline & JZB350022 & Vitis vinifera & КT021863 & NA & КТ003236 & КT070519 & КT070536 \\
\hline & JZB350023 & Vitis vinifera & KT021866 & КT021844 & КТ003240 & NA & KT070554 \\
\hline & JZB350024 & Vitis vinifera & KT021857 & KT021836 & КT003230 & NA & КT070551 \\
\hline & JZB350025 & Vitis vinifera & KT021858 & КT021837 & NA & КT070531 & NA \\
\hline & JZB350026 & Vitis vinifera & KT021856 & KT021835 & КТ003229 & КT070525 & КT070542 \\
\hline & JZB350027 & Vitis vinifera & KT021848 & KT021827 & KT003220 & NA & КT070555 \\
\hline & JZB350028 & Vitis vinifera & KT021850 & КT021829 & КТ003221 & КT070522 & КT070539 \\
\hline & JZB350029 & Vitis vinifera & KT021851 & KT021830 & KT003222 & KT070528 & KT070545 \\
\hline & JZB350030 & Vitis vinifera & KT021864 & KT021841 & KT003237 & NA & КT070553 \\
\hline & JZB350035 & Vitis vinifera & KT021852 & KT021831 & КT003223 & КT070520 & КT070537 \\
\hline & JZB350036 & Vitis vinifera & КТ021859 & КT021838 & КТ003231 & КT070523 & КТ070540 \\
\hline & JZB350039 & Vitis vinifera & KT021861 & NA & KT003233 & KT070533 & KT070557 \\
\hline
\end{tabular}


Table 1 Continued.

\begin{tabular}{|c|c|c|c|c|c|c|c|}
\hline \multirow[t]{2}{*}{ Species } & \multirow{2}{*}{$\begin{array}{l}\text { Culture } \\
\text { accession } \\
\text { numbers }{ }^{1}\end{array}$} & \multirow[t]{2}{*}{ Hosts } & \multicolumn{5}{|c|}{ GenBank accession numbers $^{2}$} \\
\hline & & & RPB2 & HSP60 & G3DPDH & Nep1 & Nep2 \\
\hline & JZB350040 & Vitis vinifera & KT021854 & NA & KT003227 & KT070532 & NA \\
\hline & JZB350041 & Vitis vinifera & NA & KT021840 & КT003234 & NA & КT070550 \\
\hline $\begin{array}{l}\text { Botrytis } \\
\text { caroliniana }\end{array}$ & $\begin{array}{l}\text { CB15 }^{*}=\text { ATCC: } \\
\text { MYA-4856 }\end{array}$ & Rubus fruticosus & JF811590 & JF811587 & JF811584 & JF811593 & NA \\
\hline $\begin{array}{l}\text { Botrytis } \\
\text { convoluta }\end{array}$ & MUCL11595 & Iris spp. & AJ745680 & AJ716069 & AJ705008 & AM087035 & AM087062 \\
\hline Botrytis croci & MUCL436 & Crocus spp. & AJ745681 & AJ716070 & AJ705009 & AM087047 & AM087065 \\
\hline $\begin{array}{l}\text { Botrytis } \\
\text { deweyae }\end{array}$ & CBS134649* & $\begin{array}{l}\text { Hemerocallis } \\
\text { spp. }\end{array}$ & HG799518 & HG799519 & HG799521 & HG799527 & HG799520 \\
\hline Botrytis elliptica & BE9714 & Lilium spp. & AJ745684 & AJ716073 & AJ705012 & AM087049 & AM087080 \\
\hline Botrytis fabae & MUCL98 & Vicia spp. & AJ745686 & AJ716075 & AJ705014 & DQ211829 & DQ211831 \\
\hline $\begin{array}{l}\text { Botrytis } \\
\text { fabiopsis }\end{array}$ & $\begin{array}{l}\text { BC-2 } *=\text { CGMCC } \\
3.13898\end{array}$ & Vicia faba & EU514473 & EU514482 & EU519211 & $\mathrm{NA}$ & $\mathrm{NA}$ \\
\hline $\begin{array}{l}\text { Botrytis } \\
\text { ficariarum }\end{array}$ & MUCL376 & Ficaria verna & AJ745688 & AJ716077 & AJ705016 & $\mathrm{AM} 087055_{\mathrm{a}}$ & $\mathrm{AM} 087085^{\mathrm{a}}$ \\
\hline $\begin{array}{l}\text { Botrytis } \\
\text { galanthina }\end{array}$ & MUCL435 & Galanthus spp. & AJ745689 & AJ716079 & AJ705018 & $\mathrm{AM} 087058_{\mathrm{a}}$ & $\mathrm{AM} 087067_{\mathrm{a}}$ \\
\hline $\begin{array}{l}\text { Botrytis } \\
\text { gladiolorum }\end{array}$ & MUCL3865 & Gladiolus spp. & AJ745692 & AJ716081 & AJ705020 & AM087040a & $\mathrm{AM} 087072_{\mathrm{a}}$ \\
\hline Botrytis globosa & MUCL444 & Allium ursinum & AJ745693 & AJ716083 & AJ705022 & AM087044a & $\mathrm{AM} 087070_{\mathrm{a}}$ \\
\hline $\begin{array}{l}\text { Botrytis } \\
\text { hyacinthi }\end{array}$ & MUCL442 & Hyacinthus spp. & AJ745696 & AJ716085 & AJ705024 & AM087048a & $\mathrm{AM} 087066_{\mathrm{a}}$ \\
\hline $\begin{array}{l}\text { Botrytis } \\
\text { narcissicola }\end{array}$ & MUCL2120 & Narcissus spp. & AJ745697 & AJ716087 & AJ705026 & AM087046 & AM087078 \\
\hline $\begin{array}{l}\text { Botrytis } \\
\text { paeoniae }\end{array}$ & MUCL16084 & Paeonia spp. & AJ745700 & AJ716089 & AJ705028 & $\mathrm{AM} 087032_{\mathrm{a}}$ & $\mathrm{AM} 087064_{\mathrm{a}}$ \\
\hline $\begin{array}{l}\text { Botrytis } \\
\text { pelargonii. }\end{array}$ & CBS 497.50 & $\begin{array}{l}\text { Pelargonium } \\
\text { spp. }\end{array}$ & AJ745662 & AJ716046 & AJ704990 & DQ211833a & DQ211834a \\
\hline $\begin{array}{l}\text { Botrytis } \\
\text { polyblastis }\end{array}$ & CBS287.38 & Narcissus spp. & AJ745702 & AJ716091 & AJ705030 & AM087039 & AM087074 \\
\hline Botrytis porri & MUCL3234 & Allium spp. & AJ745704 & AJ716093 & AJ705032 & AM087060 & AM087063 \\
\hline
\end{tabular}


Table 1 Continued.

\begin{tabular}{|c|c|c|c|c|c|c|c|}
\hline \multirow[t]{2}{*}{ Species } & \multirow{2}{*}{$\begin{array}{l}\text { Culture } \\
\text { accession } \\
\text { numbers }{ }^{1}\end{array}$} & \multirow[t]{2}{*}{ Hosts } & \multicolumn{5}{|c|}{ GenBank accession numbers $^{2}$} \\
\hline & & & RPB2 & HSP60 & G3DPDH & Nep1 & Nep2 \\
\hline $\begin{array}{l}\text { Botrytis } \\
\text { pseudocinerea }\end{array}$ & $\begin{array}{l}\text { VD110=LCP } \\
\text { 05897 }\end{array}$ & Vitis vinifera & JN692428 & JN692400 & JN692414 & NA & NA \\
\hline $\begin{array}{l}\text { Botrytis } \\
\text { ranunculi }\end{array}$ & CBS178.63 & Ranunculus spp. & AJ745706 & AJ716095 & AJ705034 & AM087054 & AM087086 \\
\hline Botrytis sinoallii & HMAS250008 & Allium spp. & EU514479 & EU514488 & EU519217 & NA & NA \\
\hline $\begin{array}{l}\text { Botrytis } \\
\text { sinoviticola }\end{array}$ & $\begin{array}{l}\text { GBC- } \\
\text { 5=CGMCC } \\
3.14977\end{array}$ & Vitis vinifera & JN692427 & JN692399 & JN692413 & NA & NA \\
\hline $\begin{array}{l}\text { Botrytis } \\
\text { sphaerosperma }\end{array}$ & MUCL21481 & $\begin{array}{l}\text { Allium } \\
\text { triquetrum }\end{array}$ & AJ745708 & AJ716096 & AJ705035 & AM087042 & AM087068 \\
\hline $\begin{array}{l}\text { Botrytis } \\
\text { squamosa }\end{array}$ & MUCL1107 & Allium сера & AJ745710 & AJ716098 & AJ705037 & AM087052 & AM087084 \\
\hline Botrytis tulipae & ВТ9830 & Tulipa spp. & AJ745713 & AJ716102 & AJ705041 & AM087037 & AM087077 \\
\hline $\begin{array}{l}\text { Sclerotinia } \\
\text { sclerotiorum }\end{array}$ & 484 & $>400$ species & AJ745716 & AJ716048 & AJ705044 & NA & NA \\
\hline
\end{tabular}

1 ATCC: American Type Culture Collection, USA; CBS: CBS-KNAW Fungal Biodiversity Centre, Utrecht, The Netherlands; CGMCC: China General Microbiological Culture Collection, China; HMAS: Institute of Microbiology, Chinese Academy of Sciences, China; JZB: Beijing Academy of Agriculture and Forestry Sciences, China; LCP: Fungal Culture Collection of the National Museum of Natural History, Paris; MUCL: Belgian Co-ordinated Collections of Microorganisms, (agro) industrial fungi and yeasts, Belgium.

${ }^{2}$ G3PDH: glyceraldehydes 3-phosphate dehydrogenase; HSP60: Heat shock protein; RPB2: RNA polymerase subunit II; Nep1and Nep2: Necrosis and ethyleneinducing protein.

${ }^{\mathrm{a}}$ sequences obtained from a different isolate than the one listed.

The most infective unit of $B$. cinerea for infection of grapevine in the spring are the conidia produced in late winter and early spring on overwintering mycelium and / or sclerotia on host tissues and on the surface of soil (Elmer \& Michailides 2004). It was reported that in Australia, the disease cycle is initiated by sclerotia in spring (Nair \& Martin 1987, Nair \& Nadtotchei 1987), but in vineyards of New Zealand sclerotia were not found (Elmer \& Michailides 2004). Seyb et al. (2000a, b) identified the dominant sources of inoculum at capfall as old rachides on the ground, tendrils, leaf petioles and cane debris. Flowers of grapevine are highly susceptible to $B$. cinerea infection when they senesce (Elmer \& Michailides 2004). With ripening, cuticle thickness and chemical composition of the berries change, increasing the susceptibility towards $B$. cinerea (Prudet et al. 1992, Commenil et al. 1997, Elmer \& Michailides 2004). Absent or thin cuticle (Marois et al. 1986) and tight bunches increases the susceptibility of 
grapes to B. cinerea (Vail et al. 1998). Botrytis outbreaks in grapevine have been shown to be associated with the grape berry moth, Lobesia botrana (Elmer \& Michailides 2004), light brown apple-moth, Epiphyas postvittana (Bailey et al. 1997) and Drosophila sp. (Capy et al. 1987).

A comprehensive phylogenetic study of the genus Botrytis was performed using three protein-coding genes (G3PDH, HSP60 and RPB2) supporting the morphological and host plantbased classification of Botrytis sp. and divided the genus into two clades (Staats et al. 2005). Clade I contained species that can only infect eudicot plants, while clade II contained species that can infect either eudicotyledonous or monocotyledonous plants. Use of these three gene regions facilitated the identification of new species in this genus (Zhang et al. 2010a, b, Li et al. 2012). Nep1 and Nep2 genes, which encode phyto-toxic proteins, have been shown to provide higher resolution in distinguishing species of Botrytis. These two gene regions evolved under positive selection, which suggested that these proteins have a role in the infection process (Staats et al. 2007a). These genes are proven to be neutral phylogenetic markers and adequate tools in phylogeny (Staats et al. 2007b, Cuesta et al. 2010, Hyde et al. 2014). This paper also contributes to the fact that Nep1 and Nep2 gene regions provide a higher resolution in distinguishing Botrytis sp.

Removal of earlier years' fruits from the trellis and fence as well as canes, bark and debris from the vineyard floor before the arrival of spring will aid in the control of Botrytis bunch rot. (Gubler et al. 1987, English et al. 1989).

\section{Acknowledgements}

The research was funded by CARS-29 and International Funds of BAAFS (2018). Kevin D. Hyde thanks the National Research Council of Thailand grants Thailands' Fungal Diversity, Solving Problems and Creating Biotechnological Products (Grant No. 61201321016) and Taxonomy, Diversity, Phylogeny and Evolution of fungi in Capnodiales (Grant No. 61215320024).

\section{References}

Albertini C, Thébaud G, Fournier E, Leroux P. 2002 - Eburicol 14a-demethylase gene (cyp51) polymorphism and speciation in Botrytis cinerea. Mycological Research 106, 1171-1178.

Aktaruzzaman M, Afroz T, Hong S-J, Kim B-S. 2017 - Identification of Botrytis cinerea, the cause of post-harvest gray mold on Broccoli in Korea. Research in Plant Disease 23, 372-378.

Bailey PT, Ferguson KL, McMahon R, Wicks TJ. 1997 - Transmission of Botrytis cinerea by lightbrown apple moth larvae on grapes. Australian Journal of Grape and Wine Research 3, 90-94.

Cappellini RA, Ceponis MJ, Lightner GW. 1986 - Disorders in table grapes shipments to the New York market, 1972- 1984. Plant Disease 70, 1075-1079.

Capy P, David JR, Carton Y, Pla E et al. 1987 - Grape breeding Drosophila communities in southern France: Short range variation in ecological and genetical structure of natural populations. Acta Oecologica-Oceologia Generalis 8, 435-440.

Chen YF, Wen JZ, Li JZ. 2006 - Research advance of grape grey mold. Journal of Northeast Agriculture University 37, 693-699.

Chomnunti P, Hongsanan S, Aguirre-Hudson B, Tian Q et al. 2014 - The sooty moulds. Fungal Diversity 66, 1-36.

Commenil P, Brunet L, Audran JC. 1997 - The development of the grape berry cuticle in relation to susceptibility to bunch rot disease. Journal of Experimental Botany 48, 1559-1607.

Cuesta AY, Kalkman E, Schouten A, Dieho M et al. 2010 - Functional analysis and mode of action of phytotoxic Nep1-like proteins of Botrytis cinerea. Physiology and Molecular Plant Pathology 74, 376-386.

Dean R, van Kan JAL, Pretorius ZA, Hammond-Kosack KE et al. 2012 - The top 10 fungal pathogens in molecular plant pathology. Molecular Plant Pathology 13, 414-430. 
Dissanayake AJ, Liu M, Zhang W, Chen Z et al. 2014 - Morphological and molecular characterization of Diaporthe species associated with grapevine trunk disease in China. Fungal Biology 119, 383-394.

Du XZ, Zhang MW, Zeng ZH, Wang SX et al. 1992 - Identification of Botrytis cinerea causing leaf blight of grapevine and preliminary study on control measures. China Fruits Issue 3, 34.

Elmer PAG, Michailides TM. 2004 - Epidemiology of Botrytis cinerea in orchard and vine crops. In: Elad Y, Williamson B, Tudzynski P, Delan N. eds. Botrytis: Biology, Pathology and Control. Dordrecht, The Netherlands: Kluwer Academic, 243-272.

English JT, Thomas CS, Marios JJ, Gubler WD. 1989 - Microclimates of grapevine canopies associated with leaf removal and control of Botrytis bunch rot. Phytopathology 79, 395-401.

Esterio M, Muñoz G, Ramos C, Cofré G et al. 2011 - Characterization of Botrytis cinerea isolates present in Thompson seedless table grapes in the Central Valley of Chile. Plant Disease 95, 683-690.

Fournier E, Levis C, Fortini D, Leroux P et al. 2003 - Characterization of Bc-hch, the Botrytis cinerea homolg of the Neurospora crassa het-c vegetative incompatibility locus, and its use as a population marker. Mycologia 95, 251-261.

Fournier E, Giraud T, Albertini C, Brygoo Y. 2005 - Partition of the Botrytis cinerea complex in $\square$ France using multiple gene genealogies. Mycologia 97, 1251-1267.

Gadoury DM, Seem RC, Wilcox WF, Henick-Kling T et al. 2007 - Effects of diffuse colonization of grape berries by Uncinula necator on bunch rots, berry microflora and juice and wine quality. Phytopathology 97, 1356-1365.

Giraud T, Fortini D, Levis C, Leroux P et al. 1997 - RFLP markers show genetic recombination in Botryotinia fuckeliana (Botrytis cinerea) and transposable elements reveal two sympatric species. Molecular Biology and Evolution 14, 1177-1185.

Giraud T, Fortini D, Levis C, Lamarque C et al. 1999 - Two sibling species of the Botrytis cinerea complex, transposa and vacuma, are found in sympatry on numerous host plants. Phytopathology 89, 967-973.

Gubler WD, Marios JJ, Bledose AM, Bettiga LJ. 1987 - Control of Botrytis bunch rot of grape with canopy management. Plant Disease 71, 599-601.

Hall TA. 1999 - BioEdit: a user-friendly biological sequence alignment editor and analysis program for Windows 95/98/NT. Nucleic Acids Symposium Series 41, 95-98.

Hennebert G, Groves J. 1963 - Three new species of Botryotinia on Ranunculaceae. Canadian Journal of Botany 41, 341-370.

Hillis DM, Bull JJ. 1993 - An empirical test of bootstrapping as a method for assessing confidence in phylogenetic analysis. Systematic Biology 42, 182.

Hyde KD, Nilsson RH, Alias SA, Ariyawansa HA et al. 2014 -One stop shop: backbones trees for important phytopathogenic genera: I. Fungal Diversity 67, 21-125.

IOV 2013 - (International Organization of vine and wine Intergovernmental Organization) World congress of vine and Wine. Statistical report on world vitiviniculture Paris, France. 18th August 2013.

Jarvis WR. 1980 - Taxonomy. In: Coley-Smith, J. R., Verhoeff, K., Jarvis, W. R., eds. The biology of Botrytis. (pp 1-17) London: Academic Press.

Jayawardena RS, Zhang W, Liu M, Maharachchikumbura SSN et al. 2014 - Identification and characterization of Pestalotiopsis-like fungi related to grapevine diseases in China. Fungal Biology 119, 348-361.

Katoh K, Toh H. 2008 - Recent developments in the MAFFT multiple sequence alignment program. Briefings in Bioinformatics 9, 276-285.

Kirk PM, Stalpers JA, Braun U, Crous PW et al. 2013 - A without-prejudice list of generic names of fungi for protection under the International Code of Nomenclature for algae, fungi and plants. IMA Fungus 4, 381-443. 
Kishino H, Hasegawa M. 1989 - Evaluation of the maximum likelihood estimate of the evolutionary tree topologies from DNA sequence data. Journal of Molecular Evolution 29, 170-179.

Leroch M, Plesken C, Weber RWS, Kauff F et al. 2012 - Grey mold population in German strawberry fields show multiple fungicide resistance and are dominated by a novel clade close to Botrytis cinerea. Applications in Environmental Microbiology 79, 159-167.

Lei BZ, Li GY, Shi ZQ. 2005 - Identification and biological characteristics of the pathogen of Botrytis cinerea on grape. Journal of Shihezi University (Nat Sci) 22 (sup.), 145-149.

Liang CH, Jayawardena RS, Zhang W, Wang X et al. 2015 - Identification and characterization of Pseudocercospora species causing grapevine leaf spot in China. Journal of Phytopathology $164,75-85$.

Li X, Kerrigan J, Chai W, Schnabel G. 2012 - Botrytis caroliniana, a new species isolated from blackberry in South Carolina. Mycologia 104, 650-658.

Marois JJ, Bledsoe AM, Gubler WD, Luvisi DA. 1986 - Control of Botrytis cinerea on grape berries during postharvest storage with reduced levels of sulphur dioxide. Plant Disease 70, 1050-1052.

Micheli PA. 1729 - Nova Plantarum Genera (Florentiae): 212, tab. 91.

Minitab Inc. 2010 - minitab release 15.1.1.0, Boston, MA, USA.

Morris JR. 1985 - Grape Juice: Influences of preharvest, harvest, and postharvest practices on quality. In Evaluation of Quality of Fruits and Vegetables (pp. 129-176). Netherlands: Springer.

Muñoz G, Hinrichsen P, Brygoo Y, Giraud T. 2002 - Genetic characterization of Botrytis cinerea populations in Chile. Mycological Research 106, 594-601.

Nair NG, Martin AB. 1987 - Ultrastructure and development of sceloria of Botrytis cinerea Pers. in vitro. Journal of Phytopathology 119, 52-63.

Nair NG, Nadtotchei A. 1987 - Sclerotia of Botrytis as a source of primary inoculum for bunch rot of grapes in New South Wales, Australia. Journal of Phytopathology 119, 42-51.

Nelson KE. 1951a - Factors influencing the infection of table grapes by Botrytis cinerea (Pers). Phytopathology 41, 319-326.

Nelson KE. 1951b - Effect of humidity on infection of table grapes by Botrytis cinerea (Pers). Phytopathology 41, 859-864.

Nylander JAA. 2004 - MrModeltest 2.0. Program distributed author. Evolutionary Biology Centre, Uppsala University.

Page RDM. 1996 - TreeView: an application to display phylogenetic trees on personal computers. Computer Applications in the Biosciences 12, 357-358.

Prudet S, Dubos B, Le MR. 1992 - Some characteristics of resistance of grape berries to gray mold caused by Botrytis cinerea. In: Verhoeff K, Malathrakis NE, Williamson B. (eds) Recent Advances in Botrytis Research. (pp 99-103) Netherlands: Pudoc Scientific Publishers, Wageningen.

Ronquist F, Teslenko M, van der Mark P et al. 2012 - MrBayes 3.2: Efficient Bayesian phylogenetic inference and model choice across a large model space. Systematic Biology 61, 539-542.

Samuel S, Papayiannis LC, Leroch M, Veloukas T et al. 2011 - Evaluation of the incidence of the G143A mutation and cytb intron presence in the cytochrome bc-1 gene conferring QoI resistance in Botrytis cinerea populations from several hosts. Pest Management Science 67, 1029-1036.

Seyb A, Jasper M, Trought M, Gaunt R et al. 2000a - The potential of vine trash as a source of Botrytis cinerea for the infection of grape (Vitis vinifera) berries. Abstracts of the XII International Botrytis symposium. Reims, France, p45.

Seyb A, Gaunt RE, Trought M, Frampton C et al. 2000b - Relationship between debris within grape bunches and Botrytis infection of berries. Proceedings of the $53^{\text {rd }}$ New Zealand Plant Protection Conference 53, 451. 
Staats M, van Baarlen P, van Kan JAL. 2005 - Molecular phylogeny of the plant pathogenic genus Botrytis and the evolution of host specificity. Molecular Biology and Evolution 22, 333-346.

Staats M, van Baarlen P, Schouten A, van Kan JAL et al. 2007a - Positive selection in phytotoxic protein-encoding genes of Botrytis species. Fungal Genetics and Biology 44, 52-63.

Staats M, van Baarlen P, Schouten A, van Kan JAL. 2007b - Functional analysis of NLP genes from Botrytis elliptica. Molecular Plant Pathology 8, 209-214.

Swofford DL. 2002 - PAUP* 4.0: phylogenetic analysis using parsimony (* and other methods). Sinauer Associates, Sunderland.

Thompson JD, Gibson TJ, Plewniak F, Jeanmougin F et al. 1997 - The Clustal X windows interface: flexible strategies for multiple sequence alignment aided by quality analysis tools. Nucleic Acids Research 24, 4876-4882.

Vail ME, Marios JJ. 1991 - Grape cluster architecture and the susceptibility of berries to Botrytis cinerea. Phytopathology 81,188-191.

Vail ME, Wolpert JA, Gubler WD, Rademacher MR. 1998 - Effect of cluster tightness on Botrytis bunch rot in six chardonnay clones. Plant Disease 82, 107-109.

Vercesi A, Toffolatti SL, Venturini G, Campia P et al. 2014 - Characterization of Botrytis cinerea populations associated with treated and untreated cv. Moscato vineyards. Phytopathologia Mediterranea 53, 108-123.

Walker AS, Gautier A, Confais J, Martinho D et al. 2011 - Botrytis pseudocinerea, a new cryptic species causing grey mold in French vineyards in sympatry with Botrytis cinerea (Phytopathology). Phytopathology 101, 1433-1445.

Wang Y, Ren X, Song X, Yu T et al. 2010 - Control of postharvest decay on cherry tomatoes by marine yeast Rhodosporidium paludigenum and calcium chloride. Journal of Applied Microbiology 109, 651-656.

Williamson B, Tudzynski B, Tudzynski P, van Kan JAL. 2007 - Botrytis cinerea: the cause of gray mold disease. Molecular Plant Pathology 8, 561-580.

Yan JY, Jayawardena MMRS, Goonasekara I, Wang Y et al. 2014 - Diverse species of Colletotrichum associated with grapevine anthracnose in China. Fungal Diversity 71, 233246.

Yan JY, Xie Y, Zhang W, Wang Y et al. 2013 - Species of Botryosphaeriaceae involved in grapevine dieback in China. Fungal Diversity 61, 221-236.

Zhang J, Wu MD, Li GQ, Yang L et al. 2010a - Botrytis fabiopsis, a new species causing chocolate spot of broad bean in central China. Mycologia 102, 1114-1126.

Zhang J, Zhang L, Li G-Q, Yang L et al. 2010b - Botrytis sinoallii: a new species of the gray mold pathogen on Allium crops in China. Mycoscience 51, 421-431.

Zhou YJ, Zhang J, Wang XD, Jiang DH et al. 2014 - Morphological and phylogenetic identification of Botrytis sinoviticola, a novel cryptic species causing grey mold disease of table grapes (Vitis vinifera) in China. Mycologia 106, 43-56. 